\title{
Prevalence of Cryptosporidium Infection among Inhabitants of 2 Rural Areas in White Nile State, Sudan
}

\author{
Seobo Sim¹, Jae-Ran Yu', Young-Ha Lee², Jin-Su Lee ${ }^{3}$, Hoo-Gn Jeong ${ }^{3}$, Abd Al Wahab Saed Mohamed4, \\ Sung-Tae Hong ${ }^{5, *}$
}

'Department of Environmental and Tropical Medicine, Research Institute of Medical Science, Konkuk University School of Medicine, Seoul 05029', Korea; '2Department of Infection Biology, Chungnam National University School of Medicine, Daejeon 35015, Korea; ${ }^{3}$ Korea Association of Health Promotion, Seoul 07653, Korea; ${ }^{4}$ Center for Schistosomiasis Control, White Nile Ministry of Health, Sudan; ${ }^{5}$ Department of Parasitology and Tropical Medicine, Seoul National University College of Medicine, Seoul 03080, Korea

\begin{abstract}
Cryptosporidium, a protozoan parasite that causes watery diarrhea, is found worldwide and is common in areas with low water hygiene. In February 2014, 866 stool samples were collected from the inhabitants of 2 rural areas in White Nile State, Sudan. These stool samples were assessed by performing modified acid-fast staining, followed by examination under a light microscope. The overall positive rate of Cryptosporidium oocysts was $13.3 \%$. Cryptosporidium oocysts were detected in $8.6 \%$ stool samples obtained from inhabitants living in the area having water purification systems and in $14.6 \%$ stool samples obtained from inhabitants living in the area not having water purification systems. No significant difference was observed in the prevalence of Cryptosporidium infection between men and women $(14.7 \%$ and $14.1 \%$, respectively). The positive rate of oocysts by age was the highest among inhabitants in their $60 \mathrm{~s}(40.0 \%)$. These findings suggest that the use of water purification systems is important for preventing Cryptosporidium infection among inhabitants of these rural areas in Sudan.
\end{abstract}

Key words: Cryptosporidium, oocyst, prevalence, water purification, Sudan

Apicomplexan parasite Cryptosporidium is found worldwide. Although Cryptosporidium infection usually causes acute selflimiting diarrhea in immunocompetent individuals, it can also result in chronic and severely dehydrating diarrhea in immunodeficient individuals. In addition, Cryptosporidium infection is associated with childhood malnutrition and growth deficits [1]. In humans, this infection develops after the ingestion of food or drinking water contaminated with Cryptosporidium oocysts [2].

Sudan is situated in the Nile Valley of Northeast Africa. Epidemiological surveys have indicated that infections caused by Schistosoma spp., soil-transmitted helminths, Plasmodium spp., and food- and water-borne protozoa are endemic to Sudan [36]. However, limited information is available on the prevalence of cryptosporidiosis in Sudan. The present study investigated the prevalence of Cryptosporidium infection among the

\footnotetext{
- Received 10 September 2015, revised 21 October 2015, accepted 21 November 2015. *Corresponding author (hst@snu.ac.kr) (C) 2015, Korean Society for Parasitology and Tropical Medicine This is an Open Access article distributed under the terms of the Creative Commons Attribution Non-Commercial License (http://creativecommons.org/licenses/by-nc/3.0) which permits unrestricted non-commercial use, distribution, and reproduction in any medium, provided the original work is properly cited.
}

inhabitants of White Nile State, which is located on the basin of the White Nile in Sudan.

In February 2014, 866 stool samples were collected from the inhabitants in 2 rural areas, Al Hidaib (186 samples) and Khour Ajwal (680 samples) (Fig. 1). Information on sex and age was available only for 776 of these 866 samples. Water purification systems were available in Al Hidaib but not in Khour Ajwal. Fecal samples obtained were directly smeared on slides and were transferred to the laboratory of Konkuk University, Seoul, Korea. The smears were stained using a modified acidfast staining method [7] and were examined under a light microscope. Samples having red oocysts of 4-5 $\mu \mathrm{m}$ in diameter were considered positive for Cryptosporidium infection. The results obtained were statistically analyzed using chi-square test, with $P<0.05$ being considered statistically significant.

Of the 866 fecal samples, 115 (13.3\%) showed the presence of Cryptosporidium oocysts. As shown in Table 1, the oocyst positive rate was higher in Khour Ajwal (14.6\%) compared to that in Al Hidaib (8.6\%) $(P=0.034)$. Overall, 14.7\% (39/266) samples obtained from men and 14.1\% (72/510) samples obtained from women had oocysts, indicating no significant difference in the prevalence of Cryptosporidium infection between 
men and women. The prevalence of Cryptosporidium infection was the highest among inhabitants in their 60s (40.0\%) followed by 40s (25.0\%), 30s (18.8\%), 20s (16.9\%), and under $10(14.9 \%)$ (Table 2).

The results of the present study showed a strong correlation between the use of water purification systems and prevalence of Cryptosporidium infection. The oocyst positive rate of inhabitants in the area having water purification systems was lower than that in the area not having water purification systems. During the rainy season and the early dry season, inhabitants of areas not having water purification systems, as Khour Ajwal, obtained drinking water from different sources such as surface water, streams, and seepage. However, in the late dry season, these inhabitants obtained drinking water from the main stream of the White Nile.

Cryptosporidiosis is a waterborne as well as a zoonotic disease, with a broad host range. We observed that cattle, the main reservoir host of Cryptosporidium, were pastured in the areas surveyed in this study. Recent studies have shown that the

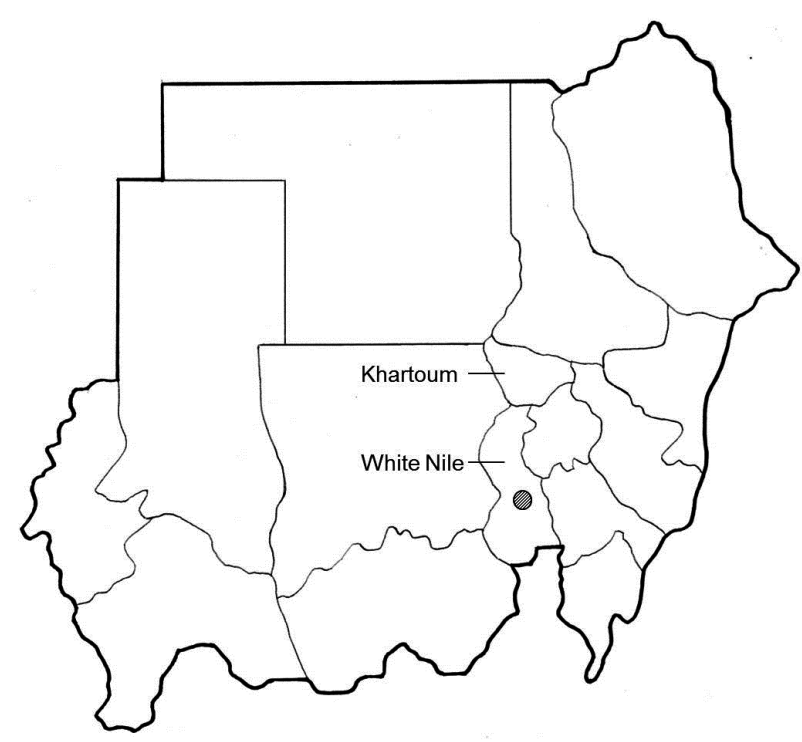

Fig. 1. Surveyed areas (-) in White Nile State, Sudan. overall prevalence of cryptosporidiosis in cattle was 7.1-31.2\% in the lower part of the Nile in Egypt, with C. parrum being responsible for $65.7-74.2 \%$ of these infections $[8,9]$. The surveyed areas are located on the basin of the White Nile, 1 of the 2 main tributaries of the Nile. Some Arab tribes usually bring their cattle into grazing areas near the shores of the White Nile.

Taken together, these findings suggest that $C$. parrum was the common Cryptosporidium species in the surveyed areas. Previous studies showed that surface water can be easily contaminated with Cryptosporidium oocysts at the end of the rainy season $[10,11]$. During the rainy season, heavy rainfall helps the spread of Cryptosporidium oocysts from cattle feces, leading to contamination of drinking water. Therefore, use of water purification systems and prohibition of grazing cattle near the shores of the While Nile are important for preventing Cryptosporidium infection.

In the present study, gender was not a risk factor for Cryptosporidium infection. This is consistent with the results of several studies performed in Ethiopia and the Philippines that did not report any gender-associated difference in the prevalence of Cryptosporidium infection $[12,13]$. This may be because of similar hygiene practices of the both sexes. The prevalence of cryptosporidiosis is high among young individuals with a weak immune system [1]. Our results showed that the prevalence of cryptosporidiosis was higher among children in Sudan than among children in surrounding countries such as Ethiopia and Egypt $[12,14]$. In our study, we also found that individuals aged 60-69 years showed the highest positive rate. This is consistent with the results of several studies that showed higher prevalence of Cryptosporidium infection in elder individuals

Table 1. Prevalence of Cryptosporidium infection among the inhabitants according to the surveyed areas

\begin{tabular}{lccc}
\hline Area & No. examined & No. positive (\%) & $P$-value \\
\hline Al Hidaib & 186 & $16(8.6)$ & 0.034 \\
Khour Ajwal & 680 & $99(14.6)$ & \\
Total & 866 & $115(13.3)$ & \\
\hline
\end{tabular}

Table 2. Age-related prevalence of Cryptosporidium infection among the inhabitants of the surveyed areas

\begin{tabular}{|c|c|c|c|c|c|c|c|c|c|c|c|}
\hline Age & & & $0-9$ & $10-19$ & $20-29$ & $30-39$ & $40-49$ & $50-59$ & $60-69$ & $>70$ & Total \\
\hline \multirow[t]{2}{*}{ Area } & Al Hidaib & $\begin{array}{l}\text { No. examined } \\
\text { No. positive (\%) }\end{array}$ & $\begin{array}{c}37 \\
5(13.5)\end{array}$ & $\begin{array}{c}64 \\
3(4.7)\end{array}$ & $\begin{array}{c}19 \\
1(5.3)\end{array}$ & $\begin{array}{c}11 \\
2(18.2)\end{array}$ & $\begin{array}{c}7 \\
2(28.6)\end{array}$ & $\begin{array}{c}6 \\
1(16.7)\end{array}$ & $\begin{array}{c}1 \\
0(0)\end{array}$ & $\begin{array}{c}1 \\
0(0)\end{array}$ & $\begin{array}{c}146 \\
14(9.6)\end{array}$ \\
\hline & Khour Ajwal & $\begin{array}{l}\text { No. examined } \\
\text { No. positive (\%) }\end{array}$ & $\begin{array}{c}312 \\
47(15.1)\end{array}$ & $\begin{array}{c}116 \\
12(10.3)\end{array}$ & $\begin{array}{c}52 \\
11(21.6)\end{array}$ & $\begin{array}{c}74 \\
14(18.9)\end{array}$ & $\begin{array}{c}45 \\
11(24.4)\end{array}$ & $\begin{array}{c}23 \\
0(0)\end{array}$ & $\begin{array}{c}4 \\
2(50.0)\end{array}$ & $\begin{array}{c}4 \\
0(0)\end{array}$ & $\begin{array}{c}630 \\
97(15.4)\end{array}$ \\
\hline Total & & $\begin{array}{l}\text { No. examined } \\
\text { No. positive (\%) }\end{array}$ & $\begin{array}{c}349 \\
52(14.9)\end{array}$ & $\begin{array}{c}180 \\
15(8.3)\end{array}$ & $\begin{array}{c}71 \\
12(16.9)\end{array}$ & $\begin{array}{c}85 \\
16(18.8)\end{array}$ & $\begin{array}{c}52 \\
13(25)\end{array}$ & $\begin{array}{l}29 \\
1(3.5)\end{array}$ & $\begin{array}{c}5 \\
2(40)\end{array}$ & $\begin{array}{c}5 \\
0(0)\end{array}$ & $\begin{array}{c}776 \\
111(14.3)\end{array}$ \\
\hline
\end{tabular}


$[15,16]$. A high prevalence of cryptosporidiosis is correlated with a close contact with cattle [12]. Therefore, elderly individuals who usually manage cattle, especially in rural areas, may have a high risk of exposure to Cryptosporidium oocysts [17].

In this study, the small numbers in the adult group in $\mathrm{Al} \mathrm{Hi-}$ daib is an obstacle for further analysis. The reason for this agerelated pattern should be assessed in future studies by detecting Cryptosporidium oocysts in livestock, surface water, wells, reservoirs, and by assessing the immunological competence of inhabitants in the surveyed areas. Efficacious vaccines and drug treatments for cryptosporidiosis are not available to date [18]. Therefore, it is necessary to build more water purification systems and sanitation facilities to improve the access of inhabitants of these areas to clean drinking water for preventing Cryptosporidium infection.

\section{ACKNOWLEDGMENTS}

The authors appreciate technical supports of staffs of the Schistosomiasis Control Center in White Nile, Sudan. The present survey was implemented as a program of "The Project for Combating Schistosomiasis in Sudan 2012-2014" which was supported by the Korea International Cooperation Agency (KOICA), Seoul, Korea.

\section{CONFLICT OF INTEREST}

We have no conflict of interest related to this work.

\section{REFERENCES}

1. Checkley W, White AC, Jr., Jaganath D, Arrowood MJ, Chalmers RM, Chen XM, Fayer R, Griffiths JK, Guerrant RL, Hedstrom L, Huston CD, Kotloff KL, Kang G, Mead JR, Miller M, Petri WA, Jr., Priest JW, Roos DS, Striepen B, Thompson RC, Ward HD, Van Voorhis WA, Xiao L, Zhu G, Houpt ER. A review of the global burden, novel diagnostics, therapeutics, and vaccine targets for Cryptosporidium. Lancet Infect Dis 2015; 15: 85-94.

2. Wilhelm CL, Yarovinsky F. Apicomplexan infections in the gut. Parasite Immunol 2014; 36: 409-420.

3. Abou-Zeid AH, Abkar TA, Mohamed RO. Schistosomiasis and soil-transmitted helminths among an adult population in a war affected area, Southern Kordofan state, Sudan. Parasit Vectors 2012; 5: 133.

4. Adam I, Elhassan EM, Haggaz AE, Ali AA, Adam GK. A perspec- tive of the epidemiology of malaria and anaemia and their impact on maternal and perinatal outcomes in Sudan. J Infect Dev Ctries 2011; 5: 83-87.

5. Ahmed AM, El Tash LA, Mohamed EY, Adam I. High levels of Schistosoma mansoni infections among schoolchildren in central Sudan one year after treatment with praziquantel. J Helminthol 2012; 86: 228-232.

6. Babiker MA, Ali MS, Ahmed ES. Frequency of intestinal parasites among food-handlers in Khartoum, Sudan. East Mediterr Health J 2009; 15: 1098-1104.

7. Casemore DP, Armstrong M, Sands RL. Laboratory diagnosis of cryptosporidiosis. J Clin Pathol 1985; 38: 1337-1341.

8. Mahfouz ME, Mira N, Amer S. Prevalence and genotyping of Cryptosporidium spp. in farm animals in Egypt. J Vet Med Sci 2014; 76: 1569-1575.

9. Helmy YA, Krucken J, Nockler K, von Samson-Himmelstjerna G, Zessin KH. Molecular epidemiology of Cryptosporidium in livestock animals and humans in the Ismailia province of Egypt. Vet Parasitol 2013; 193: 15-24.

10. Muchiri JM, Ascolillo L, Mugambi M, Mutwiri T, Ward HD, Naumova EN, Egorov AI, Cohen S, Else JG, Griffiths JK. Seasonality of Cryptosporidium oocyst detection in surface waters of Meru, Kenya as determined by two isolation methods followed by PCR. J Water Health 2009; 7: 67-75.

11. Iqbal J, Hira PR, Al-Ali F, Philip R. Cryptosporidiosis in Kuwaiti children: seasonality and endemicity. Clin Microbiol Infect 2001; 7: 261-266.

12. Wegayehu T, Adamu H, Petros B. Prevalence of Giardia duodenalis and Cryptosporidium species infections among children and cattle in North Shewa Zone, Ethiopia. BMC Infect Dis 2013; 13: 419.

13. Natividad FF, Buerano CC, Lago CB, Mapua CA, de Guzman BB, Seraspe EB, Samentar LP, Endo T. Prevalence rates of Giardia and Cryptosporidium among diarrheic patients in the Philippines. Southeast Asian J Trop Med Public Health 2008; 39: 991-999.

14. Shalaby NM. Cryptosporidium parnum infection among Egyptian school children. J Egypt Soc Parasitol 2015; 45: 125-131.

15. Seo M, Huh S, Chai JY, Yu JR. An epidemiological survey on Cryptosporidium parvum infection of inhabitants in Chorwongun, Kangwon-do. Korean J Parasitol 2001; 39: 201-203.

16. Chai JY, Lee SH, Guk SM, Lee SH. An epidemiological survey of Cryptosporidium parvum infection in randomly selected inhabitants of Seoul and Chollanam-do. Korean J Parasitol 1996; 34: 113-119.

17. Chai JY, Kim NY, Guk SM, Park YK, Seo M, Han ET, Lee SH. High prevalence and seasonality of cryptosporidiosis in a small rural village occupied predominantly by aged people in the Republic of Korea. Am J Trop Med Hyg 2001; 65: 518-522.

18. Mead JR. Prospects for immunotherapy and vaccines against Cryptosporidium. Hum Vaccin Immunother 2014; 10: 1505-1513. 
